\title{
グラフ理論による大規模都市公園のゾーニング解析
}

\section{Zoning Analysis of Large Scale Urban Parks by Graph Theory}

\author{
坂口次郎 ${ }^{*}$ 鈴木雅和 ${ }^{* *}$ \\ Jiro SAKAGUCHI Masakazu SUZUKI
}

\begin{abstract}
摘要 : 本研究の目的は, 大規模都市公園における空間構成を客観的に記述し比較検討するため,グラ フ理論に基づいたグラフの計測示数により, 空間構成を解析することにある。日本における15ヶ所 の国営公園を対象とし、ゾーニングされた空間をグラフの頂点, それらを連結する主要な動線を辺と してグラフ化を試みた。またグラフの規模, 連結度, 分散度, 関連数などのグラフ示数を計測し比較 することにより，大規模都市公園における空間構成を類型化することができた。大規模都市公園にお けるゾーニングは 1 段階だけの単純な構造ではなく, 空間を複数回分割する階層的な構造があるなど, 空間構成上の特徵が把握でき, 本解析法の有効性が確認できた。
\end{abstract}

\section{1.はじめに}

日本における国営公園を中心とした大規模都市公園は，都市に おける人口集積に伴った大量かつ広域なレクリエーション需要, また多様なレクリエーション活動に対処することを目的として整 備されている。しかし, 数百 ha 規模の大規模都市公園は, 整備 事例も少なく, 数下 $\mathrm{m}^{2}$ の街区公園, 数 ha の近隣公園, 数十 ha 規模の総合公園などの都市公園に較べて, 空間計画・設計手法の 研究は進んでおらず，また，公園の空間計画において広く用いら れているゾーニング手法は，大規模都市公園においても適用され ているが，大規模ゆえにそれを客観的に記述することが難しく， 比較研究むあまり行われていないのが現状である。

\section{2. 研究の目的}

本研究の目的は，大規模都市公園における空間構成を客観的に 記述し比較検討するため, グラフ理論 ${ }^{1)}$ に基づいたグラフの計測 示数により空間構成を捉えることにある。グラフ理論については, これまで建築・都市空間に適用した例は見られるが ${ }^{4.56)}$ ，公園空 間において適用された事例は見あたらない。本研究は，大規模都 市公園における空間構成を解読することによって, 計画・設計に おけるゾーニング手法の有効性と限界に関する知見を得ようとす るものであり，本論文は，その基礎的方法論にあたる。

3. 大規模都市公園におけるゾーニング空間のグラフ化

（1）大規模都市公園の立地環境

本研究では, 大規模都市公園として 15 の国営公園を対象とし た。表一 1 は, 国営公園の立地環境の特性を概括的に捉えるため, 地形, 公園周辺の都市の規模とその距離について整理したもので ある。国営公園の立地夕イプは丘陵型, 湖畔型, 平地型, 海浜型, 遺跡型に分類でき, 多様な地形夕イプを持った自然のポテンシャ ルが高い環境にあることがわかる。

\section{(2) グラフ理論の適用}

ゾーニングにより公園空間を捉えるに当たり，空間構成を客観 的に記述するため, グラフ理論に基づいた空間構成のグラフ化を 試みた。グラフ化は, グラフ理論の一般的な方法論を公園空間に 援用し，以下のようなプロセスによって行った。基礎資料として, 各国営公園のパンフレットに掲載されている基本計画平面図, 及 び基本計画の報告書に掲載されている平面図を用いた。 i ）各国営公園においてゾーニングされた各ゾーンをグラフの頂 点として○で表現する。

ii）各ゾーンを連結する主要な園路をグラフの迅とする。

iii）グラフの辺は頂点を連結する直線で表示し, 煩雑を避けるた めそれらがなるべく交差しないよう考慮する。

iv）グラフの全体的な形の表現は, 北を上方とし, 各公園の計画 平面図之形態的に乘離しないよう考慮する。

\section{（3）ゾーニング空間の階層構造と特徵}

当初, 各国営公園パンフレットのゾーニング図に忠実にグラフ 化を試みたが，公園によってゾーンの捉え方に空間スケールの相 違があり，そのままでは空間の比較を行うことは適切でないこと が分かった。「飛鳥」,「吉野ヶ里」を除いた全ての国営公園にお いては, ゾーニングは 1 回だけでなく, 地区，エリア，ゾーン， 施設といった名称で順次スケールを小さくしながら複数回，階層 的に行われており，その最終段階においては，おおむね空間スケ一 ルが近似している。図一 1 は, ゾーニングを $1 \sim 3$ 段階の階層構 造として表現したもので，以下の手順で作成した。

i ）各公園ごとに地区, ゾーン, エリアなどのゾーニングの段階 のグラフを集め，そのゾーニングの段階の上位から順に縦に並へ て表示した。

ii）それらのグラフを公園面積の大きい順に左から並べた。

iii）ゾーニングの段階がない部分は, 斜線を引いている。

「海中」は 1 段階で海浜, ピクニック，スポーッ，文化の $4 \supset$ のゾーンタイプに区分され，「みちのく」の 1 段階と同じ形態を している。2 段階では， 1 段階の文化のゾーンタイプがパークエ リアとリゾートエリアの 2 地区，ピクニックのゾーンタイプが自 然体験エリア，ヘルスケアエリア，リゾートタウンエリア，マリ

表－1 国営公園の立地環境マトリクス

\begin{tabular}{|c|c|c|c|c|c|c|}
\hline 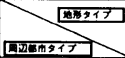 & 丘陵 & 湖畔 & 平地 & 河川 & 海浜 & 遭跡 \\
\hline 大都市群隣接 & 武麗(11) & & 昭和(17) & 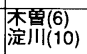 & & \\
\hline 大都市隣接 & 滝野(1) & $\begin{array}{l}\text { みちのर(2) } \\
\text { ま } ん う(1)\end{array}$ & & & $\begin{array}{l}\text { Uたち(1) } \\
\text { 海中(2) }\end{array}$ & $\begin{array}{l}\text { 瓜鳥(6*) } \\
\text { 吉野ヶ里(2) }\end{array}$ \\
\hline 大都市遠隔 & 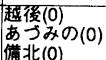 & & & & 沖縄(0) & \\
\hline
\end{tabular}

（）は公囷を中心として半径50km圈内の人口20万人以上の都市の数（93年3月現在）

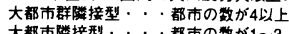

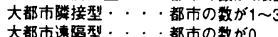

“奈良以外の都市は50km付近に集中しているため大都市陪接型とした

*住宅・都市整備公団 **筑波大学芸術学系 
ンスポーツエリアの 4 地区に分割され，1段階より複雑になって いる。3 段階になると 2 段階の各エリアがさらに分割され，施設 計画と呼ばれるスケールのレベルになっている。このグラフは細 長の公園敷地の特徴を顕著に表す形態となっており， 2 段階のグ ラフより頂点数, 辺数も大幅に増加し, さらに複雑化している。 また, 公園の南北にそれぞれ主要な出入口が設けられているが, それらの出入口部分がある公園における両端にゾーンが展開する 空間構成になっていることが分かる。このように，全体的には面 積が大きいほどゾーニングの段階が多く, 面積が小さくなるほど ゾーニングの段階が少ない傾向がある。また, 第 1 段階のゾーニ ングは比較的単純なグラフで表わされ，ゾーニングの段階が進行 するにつれてグラフの形態が複雑になる。

\section{4. グラフ構造の計測}

大規模都市公園の空間構造を客観的に捉えるため，作成したグ ラフについて，（1）グラフの全体的な構造を捉える指標群，（2） グラフの個々の要素を捉える指標群, の 2 群の指標により, グラ フ計測示数の定義式を設定した。表一 2 にその内容を示す。

(1) グラフの全体的な構造を捉える指標群による分析と考察

(i ) 構造計測示数の設定

a ) グラフの規模

グラフの規模を表すあのとして直径といわれる示数をとりあげ た。直径とは，グラフのなかで瓦いに最む離れた 2 つ頂点の間 にみられる辺の数である ${ }^{1)}$ 。大規模都市公園の空間構成のグラフ においては, グラフの規模とは公園の空間構成の複雑さ, ゾーン とゾーンとのトポロジー的距離を計測するあのである。従って, 面積の小さな公園でもある一定の性格を持ったゾーンの数が多け ればグラフ理論の規模の概念においては大きくなる。すなわち, 実際の公園面積に影響されることなく, 空間構成の複雑さについ て考察することができる。

\section{b ）グラフの連結度}

グラフの連結度を表すむのとして $\gamma$ 示数をとりあげた。 $\gamma$ 示数 は, 実際にみられるグラフの辺数の, 想定される完全連結グラフ の辺数に対する比率である ${ }^{1)}$ 。大規模都市公園におけるグラフの 連結度とは各ゾーンの全体的な関係性を計測するものであり，グ
ラフにおけるゾーン同士の関係性が高ければ数值は大きくなる。 これは比率的な示数であるため, 公園の面積によって, 或いはグ ラフの規模によって影響されることなく,ゾーン間の関連性を比 較することができる。

\section{c ）グラフの分散度}

グラフの分散度, すなわちグラフ全体のばらつきを計測するむ のとして平均分散をとりあげた。大規模都市公園の空間構成のグ ラフにおいては，ある一定の性格を持ったゾーン配置の散らばり 度を計測することになる。従って，平均分散值が大きくなれば全 体的な空間の散らばり度が大きくなり，小さくなれば全体的な空 間はまとまっているといえる。

（ii）グラフの計測示数による大規模都市公園の分類

これまで計測してきた示数を基に空間構造の特性を捉えるため, 頂点数 $\mathrm{n}$, 辺数 $\mathrm{m}$, 直径 $\mathrm{d}, \gamma$ 示数, 平均分散 $\mathrm{D}$ の 5 つのグラフ の計測示数についてレーダチャート図を作成し，大規模都市公園 の分類化を試みた。各公園のレーダチャートのなかから, 特徵的 な形態の公園を抽出した。大規模都市公園の空間構成のグラフに おいてはグラフの規模が大きくなれば連結度は低下し，一方分散 度は高くなる傾向がみられた。すなわちグラフの規模が連結度， 分散度に影響を与えていると考えられる。そのためグラフの規模 を計測する直径に着目し，その最大（「海中」 $\mathrm{d}=12$ ), 中間 (「武蔵」d=6), 最小（「飛鳥」d=2）の値を持つ 3 公園を抽出 し，図一 2 に示した（完全連結に関しては後述）。また各国営公 園をサンプルとし，各公園におけるゾーニングの最終段階の頂点 数 $\mathrm{n}$, 辺数 $\mathrm{m}$, 直径 $\mathrm{d}, \gamma$ 示数, 平均分散 $\mathrm{D}$ の 5 項目によるクラ スター分析を行った。すなわち, ゾーン数、ゾーンを連結する園 路数, 公園の全体的な空間の規模, 連結度, 分散度からみた大規 模都市公園の空間構成に関する類型化である。そのデンドログラ ムを図一 3 に示す。但し,「淀川」，「あづみの」はグラフの直径 と平均分散値がめになるため, また「木曽」については他の公園 と比較できるまで空間スケールを落とした空間構成のグラフ化が 出来なかったため，それぞれサンプルから除外した。以下，グラ フの全体的な構造の特徵に基づき, 大規模都市公園のゾーニング による全体的な空間構成に関して類型化を行った。 イ）少空間高連結型（「吉野ヶ里」「飛鳥」，「沖縄」）

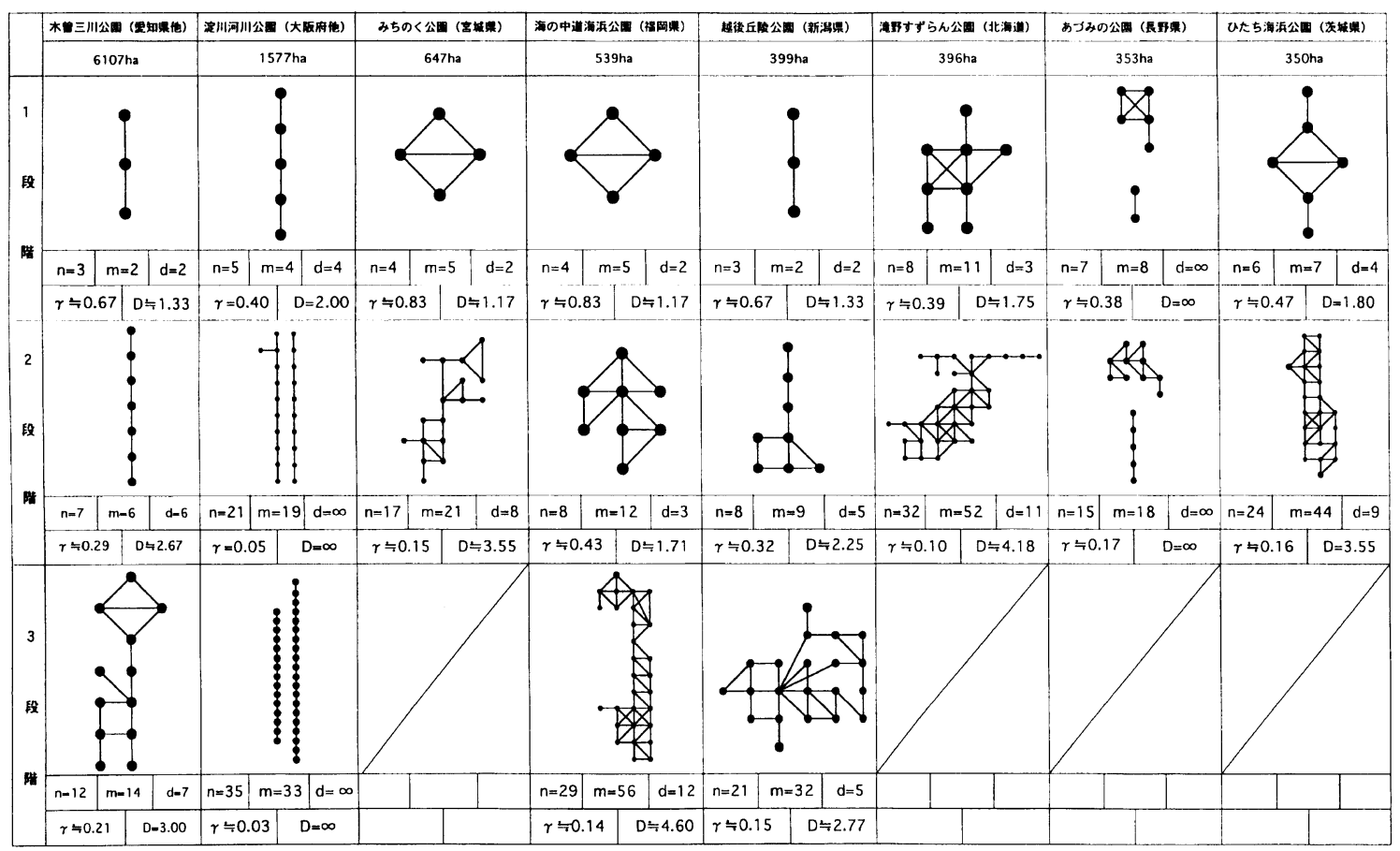

図-1＼cjkstart国営公園のグラフのマトリクス 
小面積のためゾーニングは 1 段階にとよ゙まっており，そのため ほかの公園と比べてゾーンの数が少なく $(4,7)$, 連結度が高い $(0.33,0.67)$ 。比較的単純なゾーニングタイプである。

口) 中間型（「まんのう」,「武蔵」,「みちのく」,「昭和」,「越後」, 「備北」,「常陸」)

少空間高連結型と多空間低連結型の中間型で，国営公園の中の 7 つがこの型に入る。ゾーンの数 $\mathrm{n}$, ゾーニング空間の連結度共 にイ）と八）の中間である。但し,クラスター分析でもわかるよう に, 口) 全体がイ)よりハ)の類型に近づいた形となっている。これ らは大規模な敷地をゾーニングによって多くの空間に分割しており, 1）に比べてゾーニングの段階が進行している公園タイプである。 八）多空間低連結型（「海中」，「滝野」）

大規模な敷地をゾーニングによって多くの空間に分割している。 1)，口）に比べて多くのゾーンを持ち(29,32), それらの連結度 も低い( $\gamma$ 示数 $0.10,0.14)$ 。ゾーニングによって空間を多層的に 分割した公園タイプである。

二）分散型（「木曽」,「淀川」,「あづみの」）

「木曽」については他の公園と比較できるまで空間スケールを 落とした空間構成のグラフ化はできなかったが, 立地を考慮して 「淀川」と同じ類型とした。すなわち，「木曾」，「淀川」とも河川に よって大きく敷地が 2 つに分割された河川沿いの公園である。また， 「あづみの」は河川公園ではないが，敷地が大きく2つに分かれて おり（2 地区の距離が約 $15 \mathrm{~km}$ )，これらの 3 公園はいずれもグラ フ理論のトポロジーの概念ではグラフの直径, 分散度共にのとなり, これは空間が大きく分断されていることを表わしている。そのため, ここではこれらの3 公園を分類上独立させた。但し,「沖縄」あ正 確には海洋博地区と首里城地区に分かれているが，それぞれの地区 の性格が独立しており，「あづみの」のように両地区を一体として 整備されたあのではない。従って,「あづみの」と「沖縄」とは空 間デザイン方法が異なるものと判断し, 両者を区別している。

（2）グラフの個々の要素を捉える指標群による分析と考察

(i ) 個々の要素計測示数の設定

a) 関連数

これまではグラフの全体的な構造に関する考察を行ってきたが, ここではグラフにおける個々の要素に注目する。グラフにおける
個々の要素の計測示数として関連数を設定した。関連数は, 頂点 の持つ最遠頂点までの最短パスによるトポロジー的距離のことで ある ${ }^{1)}$ 。この関連数という視点に立つと, 大規模都市公園のグラ フにおいて, 端にあるゾーンほど值が大きく, 小さな值を持つゾー ンは公園の中で中心的な位置を占めているといえる。

全体的にはゾーニングの段階が進行するにつれて各頂点の関連 数が増加し，また， 3 段階のグラフにおいて，公園の特徴之なる ゾーンタイプの関連数が低い位置となっている公園があることな どがわかった。このことについては以下に述べる。

（ii）計画意図とゾーニング手法

大規模都市公園の計画にあたっては, その敷地がもつ立地のポ テンシャルをいかに引出していくかが課題の一つといえる。「海 中」,「常陸」の 2 公園は海浜地に立地する公園であり, 大規模都 市公園のなかであ地形的に特徴を持った公園である。しかしこれ らの海浜・海水浴場ゾーンの関連数は, 図一 4 に示すように「海 中」では 8,9,11,12 であり, 特に海水浴場として計画されている 海浜・海水浴場 4 の值は 11 と全体における位置は低い。また, 「常陸」では 8 であり,「常陸」における関連数の最大が 9 である ことを考えるとこれも位置が低いといえる。同様のことが「備北」 の農場, 「常陸」の砂丘,「滝野」の谷間広場,「まんのう」の水 辺広場，についていえる。一方，関連数の少ないゾーンとしては 芝生広場 (「武蔵」,「常陸」,「滝野」,「まんのう」), 入口広場 (「武蔵」,「常陸」,「海中」,「まんのう」，「あづみの」）などを挙 げることができるが，これらのゾーンは各公園の特徴を強く表わ すむのではない。このことはゾーニングの段階を進行させること によって公園の持つ土地のポテンシャルを細分化し, その結果, それぞれの空間の関連度を低下させ，公園の特徵が生かしにくく なっていることを示している。

つまり，大規模都市公園における過度のゾーニング分割は，公 園の大規模特性, 地域特性を生かすものではなく, むしろ逆にそ れらを小さな空間に限定し, 計画のコンセプトを見えにくくして いる可能性がある。もっとも, 公園という場所においては, どの ゾーンにあすぐ行ける機能的なネットワークだけが必要とは限ら ない。また，実際には大規模都市公園のゾーンのなかには，利用 型のゾーンだけではなく, 例えばバードサンクチュアリ等の保護

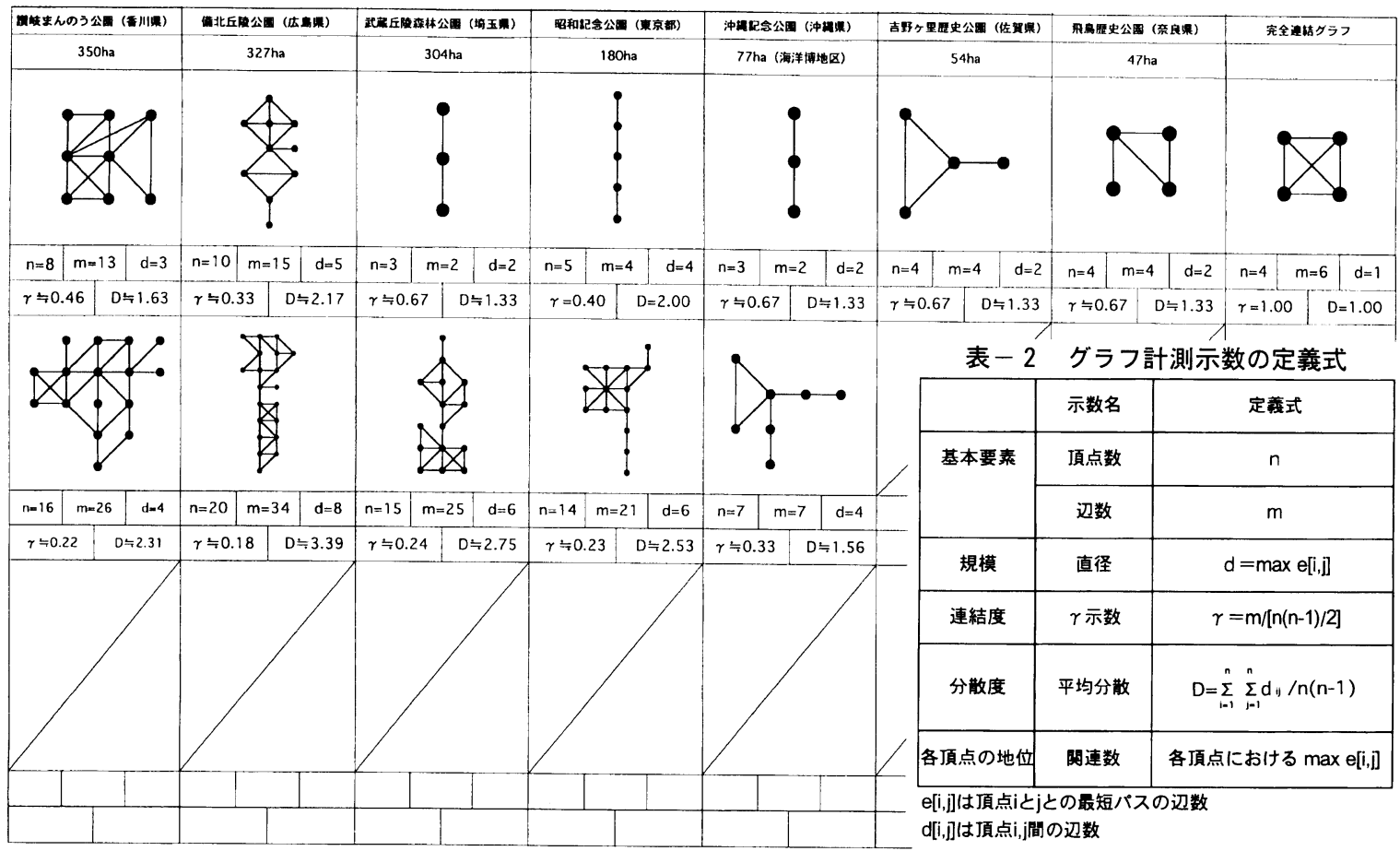



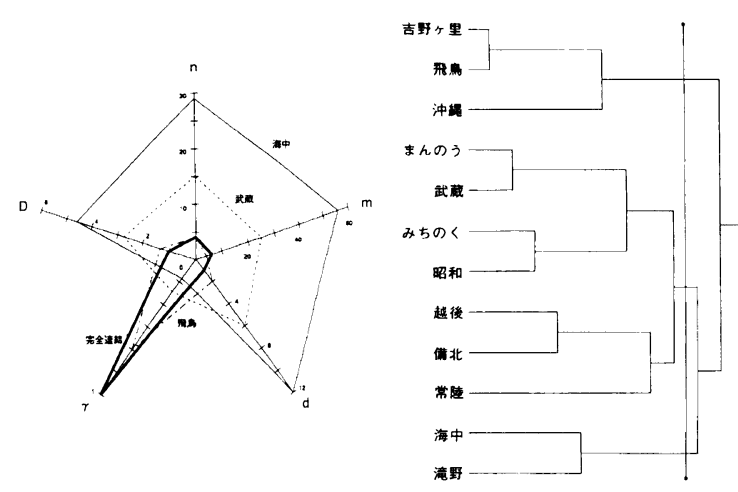

図ー2 レーダーチャート図

図ー 3 デンドログラム や保全を中心としたゾーンのように公園における全体的な空間の 位置を考えるとむしろ端にあるほうが効果的なゾーンもある。今 後グラフを応用することによって公園の各ゾーンを利用型, 保全 型という前提とし, 利用型ゾーン相互のつながり, 保全型ゾーン 相互のつながり, また利用型, 保全型相互のつながりについて把 握することが可能である。

iii）ゾーニング手法の有効性と限界

図一2 は, レーダチャートに完全連結グラフの計測示数を重ね たものである。完全連結グラフの形態は，ほかの国営公園の形態 とは大きく異なっていることがわかる。そのなかでも「飛鳥」, 「吉野ヶ里」は比較的近い形態をしているが，これらの面積はそ れぞれ 47ha,54ha であり，一般的には300ha を超えるものとさ れている国営公園においては特殊な例といえる。先に述べたよう に，「武蔵」は中間型，「海中」は多空間低連結型であり，これら はゾーニングによる空間の分割度の進行状態によって分類された ものであった。従って, ゾーニングの進行によってレーダチャー トの形態も距離 $\mathrm{d}$, 分散度 Dの值が増加し, $\gamma$ 示数が低下するに 従って, 少空間高連結型 $\rightarrow$ 中間型 $\rightarrow$ 多空間低連結型へと変形する ように, 完全連結グラフの形態から離れていくのがわかる。そし てこれは, 大規模な公園に対しても従来のゾーニング手法を用い る場合に起こりうる特徵的な現象であり，「小公園の寄り集まり」 としての大規模都市公園といった，ゾーニング手法の限界を示唆 しているあのといえる。

\section{5. 結論と今後の課題}

（1）大規模都市公園の空間構成を捉えるにあたり，公園の空間 構成のグラフ化を行い, グラフの計測示数を適用することによっ て空間全体の構造を比較分析することができる。
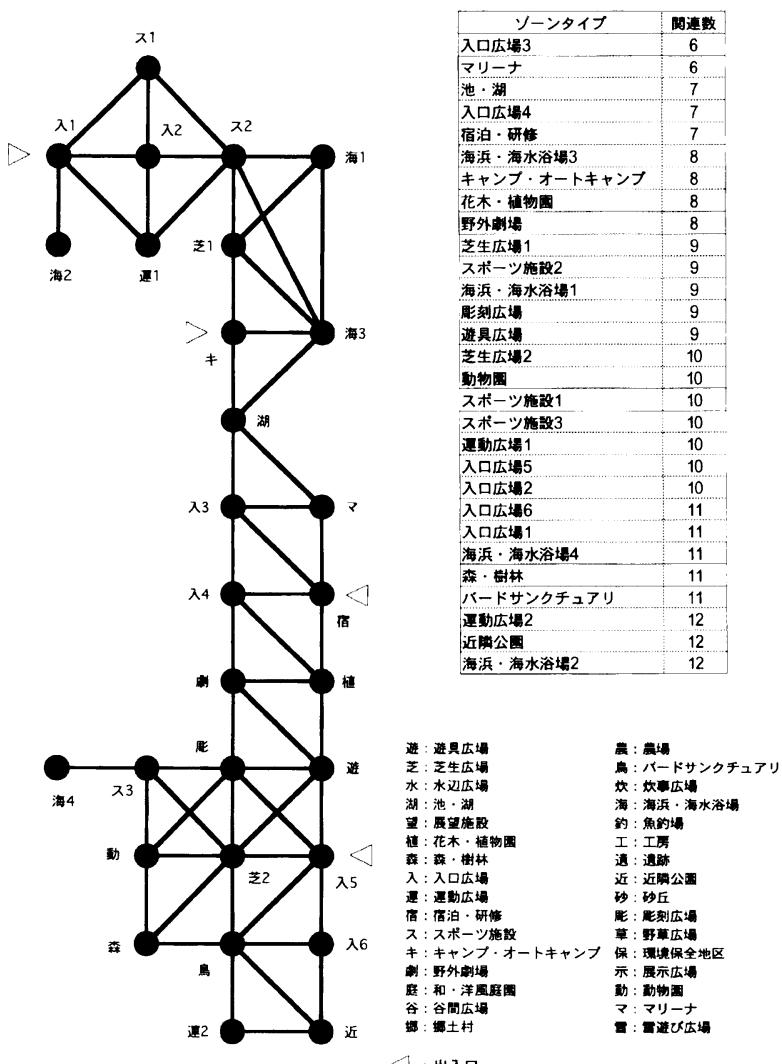

1: 出入口

図-4「海中」3 段階の関連数

（2）グラフ理論におけるネットワーク示数により，クラスター 分析を行い, レーダチャート図とともに読みとることによって大 規模都市公園を類型化できる。

（3）大規模都市公園におけるゾーニングは 1 段階だけの単純な 構造ではなく, 空間を複数回分割する階層的な構造があり, 面積 の大きい公園ほどその階層が多くなる傾向がある。またゾーニン グの段階が進行するほど公園内の空間相互の距離は遠くなり, 連 結度は低下し，分散度は高まり，全体的に複雑化傾向がある。

今後の課題として, グラフ理論・グラフの計測示数を大規模都 市公園だけでなくテーマパーク等ほかの公園に適用し比較してい くことによって, 空間デザインの特性について明らかにしていき たい。またグラフの計测示数を適用するだけでなく頂点を連結す る辺の主動線, 副動線によるランク分けなど, さらに詳しく大規 模都市公園の空間構成を解読するために応用していく必要がある。

\section{参考文献}

1）奥野隆史ほか（1976）:点之線の世界ネッ トワーク分析 : 三共出版, 1-69

2 ）小池孝幸 (1993)：大規模都市公園にお けるデザイン手法に関する研究：日本デ ザイン学会 ED プレース No.15, 6-7
3 ）佐藤昌 (1969)：地域公園の必要性とそ の管理 : 公園緑地 VOL.29, NO.2, 3-6

4 ) 高木幹朗 (1991) : グラフ・ネットワー ク指数の検討とその適用による地下街街 路構成の分析 : 日本建築学会計画系論文 報告集第 422 号, 37-44
5 ) 山中知彦ほか (1983): 計画学における グラフ理論適用に関する研究その 2 応用 編：日本建築学会論文報告集, 62-69

6 ) 渡辺健一ほか(1983)：計画学における グラフ理論適用に関する研究その 1 原理 編：日本建築学会論文報告集, $117-126$

Summary: The purpose of this study is to analyze the spatial structure of large urban parks applying Graph theory, and to consider the efficacy of Zoning method on planning and design of parks. We drew the graphs of the spatial structure of each 15 National Government Parks in Japan, consisting some vertexes as spaces designed by Zoning method and some edges as main paths between them. And we characterized these structures by defining Scale, Connection, Dispersion as the indexes of the total structures of the graphs, and Relation as the index of the hierarchy of each elements of the graphs.

The results of this study are as follows; (1) Graph theory is an effective method on analyzing spatial structure of large urban parks. (2) We can find the characteristics of parks by comparing the Graph indexes. (3) Zoning of the parks have hierarchical structure and the planning by Zoning method tends to make the spatial structure to be complicated. 